\title{
Use of phytobiotics in broiler nutrition - an alternative to infeed antibiotics?
}

\author{
M.A. Grashorn" \\ University of Hohenheim, Department of Poultry Science (470C) \\ D-70593 Stuttgart, Germany
}

(Received 24 May 2010; accepted 16 August 2010)

\begin{abstract}
After the ban of antibiotic growth promoters (AGP) in the EU many alternative substances have been investigated for their potential to replace AGPs. Phytobiotics are discussed as one promissing alternative due to their high content of pharmacologically active compounds. A huge number of in vitro and in vivo studies have confirmed a wide range of activities of phytobiotics in poultry nutrition like stimulation of feed intake, antimicrobial, coccidiostatic and anthelmintic effects. The present paper gives a short review on the characteristics of phytobiotics, on the potential mode of action and on the observed effects of phytobiotics in diets on performance, carcass and meat quality and health status in broilers. Furthermore, it addresses safety concerns which may arise during application of phytobiotics.
\end{abstract}

KEY WORDS: broiler, nutrition, growth promoters, antibiotic, phytobiotic, safety

\section{INTRODUCTION}

Conditions during fattening of animals are sometimes really stressful resulting in impaired performance. Therefore, for a long time antibiotics have been supplemented to animal diets to allow animals to cope better with these harsh conditions. Although, approved antibiotics for animal feeding were not approved for use in human medicine the increase in resistance to antibiotics in humans was ascribed to infeed growth promoting antibiotics (AGP). This led to the ban

\footnotetext{
' Corresponding author: e-mail: michael.grashorn@uni-hohenheim.de
} 
of antibiotics in animal diets in the European Union in 2006. Meanwhile, further States consider to prohibiting the use of antibiotics in animal nutrition. As a result, many substances belonging to the groups of prebiotics, probiotics, organic acids, enzymes, silicates and herbs and spices have been tested for their potential to replace AGPs in animal diets, also for poultry.

The above mentioned alternative substances are referred to as natural growth promoters (NGP; Panda et al., 2006) as most of them are of natural origin. Although, compositions of substances are very different they all act mainly in the direction of improving gut health, immune system and well being of birds.

Prebiotics are non-digestible substances, mainly oligo- and polysaccharides, lowering $\mathrm{pH}$ in the gut and by this inhibiting colonization of pathogenic microorganisms, stimulating immunity and neutralizing toxins.

Probiotics consist of single or a combination of bacteria (mainly lactic acid producing) or yeasts. Bacteria and yeasts may be included as spores or as living microorganisms. Most probiotic products available on the market contain Lactobacilli, Bacilli, Streptococci, Bifidobacterii and Sacharomcyces varieties. Probiotics act by competitive exclusion, lower gut $\mathrm{pH}$, produce bacteriocins, lysozyme and peroxides, and stimulate the immune system. The combined application of prebiotics and probiotics is called synbiotics (Panda et al., 2006).

Organic acids are used for a long time in animal nutrition. They lower gut $\mathrm{pH}$ and by this make environmental conditions less favourable for undesired bacteria. Organic acids may act directly against bacteria, also in the feed. Besides antimicrobial effects stimulation of the immune system is reported. Formic acid, propionic acid and fumaric acid are commonly used in poultry diets, whereas, butyric acid is not routinely applied.

Enzymes are widely used in animal feeds to improve utilization of nutrients. There are two major categories of enzymes used in poultry diets - phytase and cellulolytic or non-starch polysaccharides (NSP) degrading enyzmes. Phytase is supplemented to diets to make phytate phosphorus available. This may also be accompanied by a growth stimulating effect. Cellulolytic or NSP degrading enzymes have a different mode of action. Several feedstuffs (mainly cereals like barley, rye and harper) contain distinct amounts of NSP (e.g., pectin, cellulose, beta-glucans) which lower gut motility and may also reduce availability of nutrients by caging effect. NSP enzymes degrade NSP and by this improve gut motility and nutrient (mainly energy) availability.

Herbs, spices and plant extracts (mainly essential oils) are summarized under the terms botanicals, phytobiotics or phytogenics. Phytobiotics are well known for their pharmacological effects and are thus widely used in human traditional and alternative medicine. Furthermore, in human nutrition phytobiotics play an important role as flavours and food preservatives. The action of phytobiotics is 
caused by primary and secondary ingredients. A huge number of in vitro and in vivo studies have confirmed a wide range of activities of phytobiotics in animal nutrition like stimulation of feed intake, antimicrobial, coccidiostatic, anthelmintic and immunostimulating (Panda et al., 2006). In commercial poultry nutrition mainly whole seeds or extracts of black cumin (Nigella sativa), oregano (Origanum vulgare), rosemary (Rosmarinus officinalis), sage (Salvia officinalis), thyme (Thymus vulgaris) and chilli (Capsicum annum) are used singly or in combination as feed additives. Less information is available on the application of e.g., bergamot oil (Cannabis sativa) and purple coneflower (Echinacea purpurea).

The objective of the present paper is to present an overview on the composition of phytobiotics, on the probable mode of action and on observed effects on broiler performance, health and immunity and on safety issues of these components. Furthermore, some new results on the application of phytobiotics via drinking water (Echinacea and EV-herbaliq) will be presented.

\section{SPECIFICATIONS OF PHYTOBIOTICS}

Leaves, roots, flowers and whole plants are used for production of phytobiotic products. Products may comprise the dried form of whole plants or their parts or extracts of some valuable ingredients. In general, phytobiotics are described by primary and secondary plant compounds (Figure 1). Primary

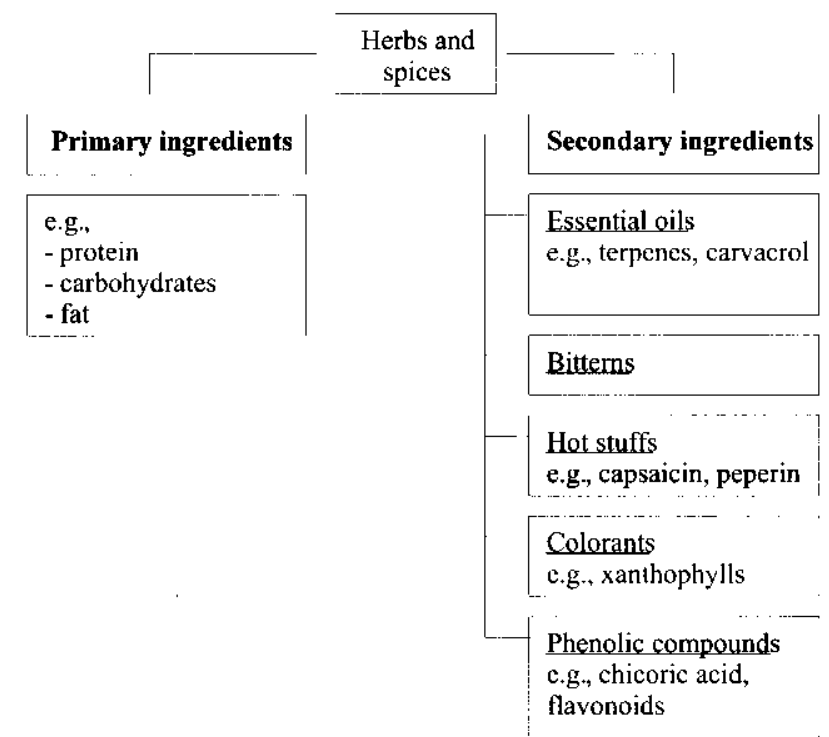

Figure 1. Composition and main ingredients of phytobiotics (after Wald, 2003) 
compounds are main nutrients (e.g., content of protein, fat, etc.), whereas, secondary compounds comprise essential (ethereal) and/or volatile oils, bitterns, hot stuffs, colorants and phenolic compounds (Wald, 2003). In general, phytobiotics do not add significantly to the intake of main nutrients in poultry. Therefore, secondary plant compounds are the main ingredients of interest.

The main constituents of essential oils are lipophilic, liquid and volatile and belong to chemical groups of alcohols, aldehydes, esters, ethers, ketones, phenols and terpenes (Máthé, 2009). Some major constituents for rosemary, sage, thyme, oregano and purple coneflower are given in Table 1. Essential oils

Table 1. Main volatile constituents of rosemary, sage, thyme, oregano and purple coneflower (Burt et al., 2004, after Mountzouris et al., 2009; Heyland et al., 2006; Nasir and Grashorn, 2009)

\begin{tabular}{|c|c|c|c|}
\hline Plant & Source & Constituent & Amount, $\%$ \\
\hline \multirow[t]{4}{*}{ Rosemary } & Teaves & $\alpha$-pinene & $2-25$ \\
\hline & & bornyl acetate & $0-17$ \\
\hline & & camfor & $2-14$ \\
\hline & & 1,8-cineole & $3-89$ \\
\hline \multirow[t]{5}{*}{ Sage } & leaves & camfor & $6-15$ \\
\hline & & $\alpha$-pinene & $4-5$ \\
\hline & & $\beta$-pinene & $2-10$ \\
\hline & & 1,8-cineole & $6-14$ \\
\hline & & a-tujone & $20-42$ \\
\hline \multirow[t]{4}{*}{ Thyme } & leaves & thymol & $10-64$ \\
\hline & & carvacrol & $2-11$ \\
\hline & & $\gamma$-terpentine & $2-31$ \\
\hline & & p-cymene & $10-56$ \\
\hline \multirow[t]{4}{*}{ Oregano } & leaves & carvacrol & $<1-80$ \\
\hline & & thymol & $<1-64$ \\
\hline & & $\gamma$-terpentine & $2-52$ \\
\hline & & p-cymene & $<1-52$ \\
\hline Purple coneflower & leaves, roots & chicoric acid & 27 \\
\hline
\end{tabular}

as flavours stimulate the digestive system and by this improve nutrient digestibility. Furthermore, essential oils act against oxidative processes, and growth of bacteria and moulds, both in the gastrointestinal tract (GIT) and in the feed (Table 2).

Bitterns and hot stuffs are of less importance as most phytobiotics contain only small amounts of these ingredients. Bitterns are reported for thyme and sage (carnesol) and hot stuffs for chilli (capsaicin) (Heyland et al., 2006). It is well documented that poultry is in favour of bitter taste, whereas, high contents of hot stuffs result in feed rejection.

Natural colorants (xanthophylls) are included in most phytobiotics. The dominant xanthophylls are lutein, zeaxanthin, $\beta$-carotene and lycopene. In chilli capsanthin and capsorubin are responsible for the red colour. Xanthophylls are 
Table 2. Effects of essential oils on animal physiology (after Günther, 1990)

\begin{tabular}{ll}
\hline Effect & Physiological action \\
\hline Intensification of taste & Impulses to central nervous system \\
Increased secretion of digestive juices & Improved digestion \\
Increased activity of digestive enzymes & Improved nutrient digestion and absorption \\
$\begin{array}{l}\text { Inhibition of oxidative processes } \\
\begin{array}{l}\text { Inhibition of growth of bacteria and fungi in feed } \\
\text { and GIT }\end{array}\end{array}$ & $\begin{array}{l}\text { Reduced level of peroxides in the GIT } \\
\text { Reduction of toxins }\end{array}$ \\
\hline
\end{tabular}

antioxidants and show partly pro-vitamin A activity. Antoxidative capacity of colorants is yet not very intensively investigated in poultry as the major antioxidants in diets are selenium and vitamin E. Provitamin A activity is normally of minor interest as commercial diets are supplemented with sufficient amounts of vitamin A. Due to the normally low supplementation level of phytobiotics to broiler diets the colouring effect is less pronounced.

Various phenolic compounds are included in phytobiotics with flavonoids and chicoric acid being the dominating ones (Panda et al., 2006; Nasir and Grashorn, 2009). The pharmacological effects of phenolic compounds are still not known very well, but, it is believed that they exhibit antioxidative effects due to their chemical structure.

\section{PHYTOBIOTIC PREPARATIONS AS FEED AND WATER ADDITIVES}

Ingredients of phytobiotics may vary distinctly due to climatic conditions, soil, species, time of harvest, degree of maturation, included parts, etc. (Wald, 2003). This holds mainly for products of dried whole plants or parts. Extracts of essential oils or oleoresins show less variation. In animal feeding phytobiotics are used as single preparations (e.g., oregano, thyme, garlic, Echinacea) or as mixtures (plant extracts, herb mixes, spice mixes, oil blends). Meanwhile, the number of available products is too big to name all. Some examples are given by Sarma and Sapcota (2000): Liv-52, Livol, Tefroli, Crown Grofit, Lomoton, Plumchic and Livfit. Further additives common in Germany are Digestarom (Branscheid et al., 1998; Damme, 1998, 1999) and Cuxarom Spicemaster (brown algae with anise, basil, fennel, garlic, thyme and cinnamon; Wald, 2003), Sangrovit (sanguinarin), Crina and Xtract (carvacrol, cinnamon aldehyde). In developing countries herbal preparations are used traditionally for improvement of poultry health (Okitoi et al., 2007). Supplementation levels of products to poultry diets vary between 0.1 and $40 \mathrm{~g} / \mathrm{kg}$ for dried products and plant extracts, whereas, essential oils and single plant ingredients (e.g., thymol, carvacrol) are supplemented at a distinctly lower level $(0.02-1.0 \mathrm{~g} / \mathrm{kg}$; Windisch et al., 2009). Supplementation of extracts or essential oils to drinking water is even lower due to the higher water than feed intake (about 1.8:1). 


\section{PHYTOBIOTICS IN BROILER PRODUCTION}

Phytobiotics have gained increasing interest as natural growth promoting feed additives in broiler production in recent years. Nevertheless, knowledge on modes of action as well as aspects of application are still rather limited (Windisch et al., 2009). Furthermore, original plants included in phytobiotic products vary widely in their composition and content of active ingredients making it difficult to estimate the mode of action. Some actions may only be possible when a defined combination of ingredients is available.

Phytogenic effects have been proven in poultry for feed palatability and quality (sensory aspects), growth promotion (improved weight gain and feed conversion ratio, reduced mortality), gut function and nutrient digestibility (improved growth), gut microflora (less diseases of the GIT, improved growth, reduced mortality), immune function (improved health), and carcass meat safety and quality (reduced microbial load, improved sensory)(after Mountzouris et al., 2009).

Windisch et al. (2009) analysed literature data for proven effects of phytobiotic feed additives in different poultry species. In average phytobiotics as plant extracts reduced feed intake by $2.1 \%(-8$ to +3$)$, did not really change body weight $(+0.08 \% ;-8$ to +14$)$ and daily weight gain $(-0.3 \% ;-3$ to $+3 \%)$, and improved feed conversion ratio by $3.4 \%(-17$ to $+2 \%)$ in broilers. The application of dried herbs and spices increased feed intake by $1.3 \%$, decreased body weight by $1.5 \%$, increased average daily weight gain by $2.6 \%$ and improved feed conversion ratio by $0.14 \%$. Results for turkeys and quails showed a comparable pattern.

Phytogenic substances show a clear antimicrobial activity in vivo (e.g., Okitoi et al., 2007). In the same way anticoccidial effects of phytobiotics are described (Giannenas and Kyriazakis, 2009). The observed effects are probably caused by the potential of hydrophobic essential oils to intrude the bacterial cell membrane, to disintegrate membrane structure and to cause ion leakage (Windisch et al., 2009). Nevertheless, more research is needed to clearify this specific action of phytobiotics.

Effects on gut morphology are obviously twofold. On the one side phytobiotics irritate intestinal tissues leading to shortage of intestinal surface and on the other side change the microbial population to a more favourable composition. Furthermore, they result in an enhanced secretion of digestive enzymes resulting in an improved gut functioning (Windisch et al., 2009).

\section{Echinacea purpurea as water supplement}

Purple coneflower (Echinacea purpurea - EP) is widely used in human and laboratory animals due to its immunostimulating effects. It contains as active 
substances alkamides, glycoproteins, polysaccharides, phenolic compounds, cinnamic acids, essential oils and flavonoids (Nasir and Grashorn, 2010). Solutions and extracts of EP show proven macrophage activity and anti-inflammatory and antioxidant properties. Due to its immunostimulating effects EP has to be administered in intervals. Normally, this excludes supplementation to feed although in some experiments positive effects have been observed (Roth-Maier et al., 2005). In general, knowledge on the use of EP in poultry production is still limited. Although, some information on the effects of EP on performance of broilers and layers is available, results on safety are scarce.

In a project, the effects of EP fermented juice supplemented to drinking water in different doses and application times were investigated on performance, metabolism, immunity and stress parameters in Ross 308 broilers. The EP product $(6.5 \%$ dry matter, chicoric acid $2.77 \mathrm{mg} / \mathrm{ml}$, total alkamides $3.95 \mathrm{mg} / \mathrm{ml}$; Berghof Kräuter, Heilsbronn, Germany) was added to drinking water in amounts of $0.0,0.25,0.50,1.00$ and $2.50 \mathrm{ml} / \mathrm{kg} \mathrm{BW} \mathrm{BW}^{0.75}$ and as a preparation on ethanol basis. Application time was 3 days followed by 9 days without EP supplementation. Broilers tolerated up to $2.5 \mathrm{ml} / \mathrm{kg} \mathrm{BW}{ }^{0.75}$, but performance decreased with increasing supplementation levels (Table 3). Blood parameters did not indicate any negative effect on liver metabolism or induced stress, but a significantly higher immunity level (globulin concentration as indicator of immunglobulins) and improved stress compensation. From the experiments it could be concluded that $0.25 \mathrm{ml} / \mathrm{kg} \mathrm{BW}^{0.75}$ was sufficient to induce growth promoting effects without safety concerns.

Table 3. Effects of Echinacea purpurea in drinking water on performance and blood serum parameters in broilers in comparison to unsupplemented control (Nasir and Grashorn, 2010)

\begin{tabular}{lcc}
\hline Item & Control & $\mathrm{EP}\left(0.25 \mathrm{ml} / \mathrm{kg} \mathrm{BW}^{0.75}\right)$ \\
\hline Final weight d 35, g & 1802 & 1828 \\
ADWG, g & 47.5 & 51.0 \\
Feed consumption, g & 2577 & 2643 \\
FCR, g fecd/g gain & 1.67 & 1.63 \\
Dressing, \% & 70.6 & 71.3 \\
Blood parameters & & \\
total protein, mg/dl & 3.10 & 3.21 \\
globulin, mg/dl & $1.53^{\mathrm{b}}$ & $1.69^{\mathrm{a}}$ \\
ALT, U/l & 5.08 & 4.00 \\
$\gamma$-GT, U/1 & 22.2 & 21.8 \\
ALP, U/1 & 3267 & 2416 \\
CK, U/l & $23892^{\mathrm{a}}$ & $15180^{\mathrm{b}}$ \\
erythrocytes, T/l & 2.27 & 2.29 \\
lcucocytes, G/l & 7.58 & 6.02 \\
\hline ADD & & \\
\hline
\end{tabular}

ADWG - average daily weight gain; FCR - feed conversion ratio; ALT - alanine amino transferase; $\gamma$-GT - gamma-glutamyl-transferase; ALP - alkaline phosphatise; CK - creatine kinase 


\section{EV-herbaliq 100}

The phytobiotic EV-herbaliq 100 contains essential oils of anise, basil, cress, caraway, sage and cinnamon (Extra-Vit GmbH, Möhnesee, Germany). Thebioactive compounds included in this product are believed to improve gut and immune function and by this enhance performance and well-being. In an experiment with Ross 708 broilers EV-herbaliq 100 was supplemented to drinking water in doses of $0,250,500$ and $750 \mathrm{ml} / 1000 \mathrm{l}$. Final body weight and average daily weight gain (ADWG) increased with supplementation level of EV-herbaliq (Table 4). Final body weight was 5.5 to $7.0 \%$ higher in EV-herablic groups than in control group.

Table 4. Effects of different levels of EV-herbaliq 100 in drinking water on performance and meat quality criteria in broilers

\begin{tabular}{lcccc}
\hline Item & Control & $250 \mathrm{ml} / 10001$ & $500 \mathrm{ml} / 10001$ & $750 \mathrm{ml} / 1000 \mathrm{l}$ \\
\hline Final weight, g & $1663^{\mathrm{b}}$ & $1757^{\mathrm{b}}$ & $1754^{\mathrm{b}}$ & $1780^{\mathrm{b}}$ \\
ADFl, g & 87 & 88 & 87 & 91 \\
ADWI, g & 177 & 177 & 181 & 189 \\
FCR, g/g & 1.70 & 1.56 & 1.58 & 1.63 \\
Breast meat & & & & \\
$\quad$ breast yield, \% & 29.2 & 30.2 & 31.4 & 31.9 \\
$\mathrm{~L}^{*}$ & 48.0 & 48.1 & 48.5 & 49.1 \\
$\mathrm{a}^{*}$ & 2.2 & 1.3 & 1.2 & 1.6 \\
$\mathrm{~b}^{*}$ & 5.7 & 6.8 & 7.6 & 8.3 \\
cooking loss, \% & $18.4^{\mathrm{b}}$ & $20.9^{\mathrm{a}}$ & $18.9^{\mathrm{b}}$ & $19.4^{\mathrm{b}}$ \\
\hline
\end{tabular}

ADFI - average daily feed intake; ADWI - average daily water intake; FCR - feed conversion ratio; $L^{*}$ - brightness, $a^{*}$ - redness, $b^{*}$ - yellowness of breast meat

Feed and water consumption was higher for treatment groups than for control resulting in an improved feed conversion ratio. FCR was improved by $8.6,7.4$ and $4.7 \%$ for treatments 250,500 and $750 \mathrm{ml} \mathrm{EV-herabliq/1000} \mathrm{l}$ in regard to control, respectively. Carcass yield did not differ between groups, but breast meat yield was higher for 500 and $750 \mathrm{ml}$ supplementation. Brightness and yellowness of meat increased and redness decreased with increasing supplementation level. In the same way a higher cooking loss was observed. Thus, results indicate clear growth promoting effects, but a probable negative effect on meat quality.

\section{SAFETY ISSUES OF PHYTOBIOTICS}

Phytobiotics contain many pharmacologically active components which play a major role in the defence system of the plant. From this point of view safety concerns cannot be excluded, although, phytobiotics are generally assumed as GRAS (Generally Recognized as Safe; Wald, 2003; Máthé, 2009). Phytobiotics 
contain as well irritating ingredients which may be harmful to both animals and humans. Furthermore, undesired residues may not be excluded in a natural product. In several experiments it was observed that bioactive ingredients or their metabolites may be transferred to tissues (Windisch et al., 2009). Some, concerns are reported for capsaicin (cancer causing), cyanide containing ingredients, carvacrol (in oregano) and glycosides. The content of capsaicin in chilli (paprika) is limited by EU regulation (only regulated for paprika as food additive E160c, $<250 \mathrm{mg} / \mathrm{kg}$; EU, 1995) due to probable toxic effects. Few information is available on metabolites deposited as residues to tissues resulting in impaired sensory attributes (Kluth et al., 2003). In general, for probable negative effects the dose is important. High inclusion levels of oregano may affect the minimum inhibitory concentration (MIC) for antibiotics (Mountzouris et al., 2009). For rats the LD50 value was reached for oregano oil for a dose 100 times the normal supplementation level in feed (Wald, 2003). The observed results indicate the necessity to check phytobiotics thoroughly for potential safety issues.

\section{CONCLUSIONS}

In poultry meat production birds have to face several challenges (climatic conditions, changes of feed, microbial load, stress during rearing) disturbing the normal functioning of the organism. Mainly, the gastrointestinal tract may be influenced resulting in impaired absorption of nutrients and by this in reduced performance and increased mortality. Therefore, in the past antibiotics were supplemented to diets to make birds cope better with harsh conditions during the rearing period. With the ban of antibiotics as infeed growth promoters (AGPs) farmers lost an effective tool to help birds to realize their performance capacity. Many alternative substances belonging to very different groups of additives have been tested meanwhile for their potential to replace AGPs. Phytobiotics seem to be the most promising ones as they are of natural origin and as they are generally regarded as safe (GRAS), although, they contain a broad number of pharmacologically active substances with widely unknown action. Experiments with various products conducted with broilers up to now show a clear tendency for improved performance and health status, although the net margin amounts only to few percents in regard to tested negative control groups. But, this is typical for feed additives as distinct effects may only be realized under really harsh production conditions which should be avoided in practical production. The generally lower effects of phytobiotics in regard to AGPs are due to the different modes of action of both groups of supplements. 


\section{RFERENCES}

Branscheid W., Ristic M., Dobrowski A., 1998. Broilerfütterung mit Kräutem: Auswirkungen auf die Schlachtkörperqualität? DGS Magazin 50 (23), 26-30

Damme K., 1998. Phytogene Verdauungsförderer - eine Alternative zu Fütterungsantibiotika? DGS Magazin 50 (14), 26-30

Damme K., 1999. Was bringen phytogene Verdauungsförderer in der Putenmast? DGS Magazin 51 (13), 32-35

EU, 1992. Commission Directive 95/45/EC Laying Down Specific Purity Criteria Concerning Colours For Use in Foodstuffs

Giannenas I., Kyriazakis I., 2009. Phytobased products for the control of intestinal diseases in chickens in the post antibiotic era. In: T. Steiner (Editor). Phytogenics in Animal Nutrition. Nottingham University Press, Nottingham, ISBN 978-1-904761-71-6

Günther K.D., 1990. Gewürzstoffe können die Leistung erhöhen. Kraftfutter 73, 469-474

Heyland K.-U., Hanus H., Keller E.R., 2006. Ölfrüchte, Faserplanzen, Arzneipflanzen und Sonderkulturen. Eugen Ulmer Stuttgart, ISBN 978-3-8001-3203-4

Kluth H., Schulz E., Halle I., Rodehutscord M., 2003. Zur Wirksamkeit von Kräutern und ätherischen Ölen bei Schwein und Geflügel. Lohmann Infor. No 2, 9-14

Máthé Á., 2009. Essential oils: biochemistry, Production and utilisation. In: T. Steiner (Editor). Phytogenics in Animal Nutrition. Nottingham University Press, Nottingham, ISBN 978-1904761-71-6

Mountzouris K.C., Paraskevas V., Fegeros K., 2009. Phytogenic compounds in broiler nutrition. In: T. Steiner (Editor). Phytogenics in Animal Nutrition. Nottingham University Press, Nottingham, ISBN 978-1-904761-71-6

Nasir Z., Grashorn M.A., 2009. Echinacea: A potential feed and water additive in poultry and swine production. Arch. Geflugelk. 73, 227-236

Nasir Z., Grashorn M.A., 2010. Effects of intermittent application of different Echinacea purpurea juices on broiler performance and some blood parameters. Arch. Geflugelk. 74, 36-42

Okitoi L.O., Ondwasy H.O., Siamba D.N., Nkurumah D., 2007. Traditional herbal preparations for indigenous poultry health management in Western Kenya. Livest. Res. Rural Develop. 19 (5) (http://www.cipav.org.co/Irrd19/okit19072.htm)

Panda K., Rama Rao S.V., Raju M.V.L.N., 2006. Natural growth promoters have potential in poultry feeding systems. Feed Tech. $10(8), 23-25$

Roth-Maier D.A., Böhmer B.M., Maass N., Damme K., Paulicks B.R., 2005. Efficiency of Echinacea purpurea on performance of broilers and layers. Arch. Geflugelk. 69, 123-127

Sarma M., Sapcota D., 2000. Ecofriendly broiler production through herbal growth promoters. Poultry Planner 1 (11), 10-14

Wald Chr., 2003. Gewürze und Co - eine Übersicht. Lohmann Inform. No. 3, 7-11

Windisch W., Rohrer E., Schedle K., 2009. Phytogenic feed additives to young piglets and poultry: mechanisms and application. In: T. Steiner (Editor). Phytogenics in Animal Nutrition. Nottingham University Press, Nottingham, ISBN 978-1-904761-71-6 